\title{
REVITALISASI KEBIJAKAN \\ PEMBANGUNAN KEHUTANAN DI KALIMANTAN TIMUR PERIODE LIMA TAHUN KE-2 OTONOMI DAERAH (2006-2010)
}

\author{
Oleh: H. Rusdi Manaf ${ }^{6}$ dan Daroni ${ }^{7}$
}

\begin{abstract}
East Kalimantan's natural resources have been the main sector in terms of financial contribution to the national income. Reforestration fund, provision of forest resources, export taxes, and other significant levies, have taken essential part in bearing the national development processes. This implies the positive roles of Kalimantan forest, for which it should be properly managed. Until recently, unfortunately, forest management has been observed to be unsuccsesful as indicated by depletion and degradation of forest areas during the first period of the implementation of regional autonomy (2001-2005). Under the new vision "forest management for the shake of resource sustainability and people's wellbeing”, the following efforts are truthfully required: reassessment of performance measurement, revitalization through soft landing, reinforcing forest rehabilitation movement, reevaluation of policies concerning administrative approval (perijinan), etc. The ultimate goal of such endeavors is to achieve the optimum equilibrium of the forest function, i.e. between economic interest and ecological interest.
\end{abstract}

Keywords: kinerja kehutanan, kapasitas kelembagaan, restrukturisasi dan revitalisasi, peranan ekologis dan sosial ekonomi hutan.

\section{Latar Belakang}

Propinsi Kalimantan Timur mempunyai luas daratan sekitar $200.395 \mathrm{~km}^{2}$, merupakan Propinsi terbesar di Indonesia. Luas daratan Kalimantan Timur kira-kira sama dengan satu setengah kali Pulau Jawa dan Madura. Dari luas tersebut, 15,952 juta hektar atau sekitar 75 persennya adalah berupa kawasan hutan (hutan suaka alam dan wisata, hutan lindung, hutan produksi terbatas, hutan produksi tetap dan hutan penelitian) dan 4,088 juta hektar merupakan hutan produksi yang dapat dikonversi.

Kawasan hutan tersebut meliputi kawasan hutan suaka alam dan hutan lindung seluas 2,752 juta hektar (17,252\%), hutan penelitian 23,5 ribu hektar $(0,15 \%)$ dan Kawasan budidaya kehutanan (hutan produksi tetap dan hutan produksi terbatas) Kalimantan Timur

\footnotetext{
6 Ir. H. Rusdi Manaf, M.Si adalah Plt. Kepala Dinas Kehutanan Propinsi Kalimantan Timur.

7 Dr. Daroni, SIP.,SP.,MP adalah Staf Dinas Kehutanan Provinsi Kalimantan Timur dan Staf Pengajar STIEM Samarinda
} 
seluas 9,711 juta hektar ( $60,88 \%$ ), dan Kawasan budidaya non kehutanan 2.165 juta hektar $(13,57 \%)$.

Selama 3,5 dasawarsa, sumberdaya hutan khususnya hutan produksi Kalimantan Timur diusahakan secara intensif dan telah memberikan sumbangannya yang besar bagi penerimaan negara untuk pembiayaan pembangunan yang berasal dari pungutan-pungutan Dana Reboisasi (DR), Iuran Hasil Hutan/Provisi Sumberdaya Hutan (IHH/PSDH), pajak ekspor dan pungutan-pungutan lainnya cukup signifikan dalam menopang biaya pembangunan nasional. Serangkaian dampak positif dari pengelolaan hutan Kalimantan Timur cukup mempunyai arti dalam memberikan kontribusi terhadap penerimaan negara, penyerapan tenaga kerja, mendorong perkembangan wilayah dan pertumbuhan ekonomi daerah/regional.

Setelah puluhan tahun pengelolaan hutan dengan persetujuan kehutanan (forestry agreement) dengan sistem sekarang ini, dinilai masih belum berhasil dalam tujuan pengelolaan hutan seperti konsep Tebang Pilih Indonesia (TPI), Tebang Pilih Tanam Indonesia (TPTI), atau Tebang Jalur Tanam Indonesia (TJTI) dan sistem pengelolaan hutan lainnya. Kecenderungan yang terjadi adalah bahwa kawasan hutan hingga era otonomi daerah 5 tahun I semakin mengalami penciutan/penyusutan (depletion) dan bahkan terjadi degradasi yang cukup serius akibat eksploitasi, deforestrasi sumberdaya hutan secara besar-besaran.

Peranan dari hutan alam sebagai sumberdaya strategis untuk pembangunan ekonomi menjadi semakin penting mengingat semakin meningkatnya permintaan akan kayu dunia. Oleh karena itu upaya untuk mempertahankan kelestarian hutan dengan menerapkan konsep Sustainable Forest Management (SFM) menjadi sangat penting dan perlu terus ditingkatkan.

Sesungguhnya sumberdaya hutan di Kalimantan Timur merupakan sektor kunci (key sector), seharusnya pemanfaatan atau pengusahaan hutan dapat memacu perkembangan pembangunan disektor-sektor non migas lainnya. Kontribusi dari hasil Industri kehutanan Kalimantan Timur selama lima tahun terakhir (Otonomi Daerah 5 tahun I) mencapai US \$ 2,669 juta atau sekitar Rp23 trilyun. Selain itu, kemajuan yang diikuti dengan peningkatan pendapatan di sektor kehutanan harus dapat merembes ke bawah (tricle down effect) pada lapisan masyarakat paling bawah, dan yang penting lagi adalah kepada masyarakat yang hidup di desa sekitar hutan.

Dalam kenyataannya pemanfaatan atau pengusahaan hutan dimasa silam belum memberikan respon yang memuaskan terhadap fungsinya sebagai sektor kunci. Program PMDH yang telah berjalan puluhan tahun ternyata tidak meninggalkan bekas. Pemberdayaan ekonomi masyarakat di sekitar kawasan hutan tidak berkembang. Ini artinya bahwa program mengentaskan kemiskinan masyarakat desa di sekitar hutan masih sangat jauh dari apa yang menjadi tujuan. Program yang terlalu makro tidak mampu menjawab transformasi masyarakat yang bersinggungan dengan persoalan hutan.

Dampak pembangunan kehutanan Kalimantan Timur terhadap peningkatan kesejahteraan masyarakat tidak cukup signifikan sebagai akibat adanya proses marginalisasi masyarakat di sekitar hutan. Hal ini dapat dilihat dengan masih banyaknya masyarakat di sekitar hutan yang hidup dalam kategori miskin yang dapat memicu terjadinya gap karena adanya kesenjangan sosial.

Ketidak seimbangan antara orientasi ekonomi dan kelestarian lingkungan dalam pemanfaatan hasil hutan kayu yang berlebihan dan lajunya perubahan kawasan hutan untuk kepentingan pembangunan non kehutanan, menyebabkan timbulnya berbagai permasalahan 
sosial, ekonomi dan lingkungan. Degradasi hutan yang terjadi dengan rataan per tahun 700 ribu hektar selama kurun waktu lima tahun terakhir ini merupakan akibat dari pengelolaan hutan yang kurang memperhatikan aspek-aspek kelestarian. Pembukaan kawasan hutan dalam skala besar dalam berbagai kepentingan pembangunan, penebangan yang berlebihan (over cutting) dan persoalan illegal logging dan illegal timber trade yang belum ada kesepahaman pandangan (visi) diantara pihak terkait.

Belum lagi persoalan perambahan hutan, okupasi lahan dan kebakaran hutan yang cukup memberikan andil terjadinya degradasi hutan Kalimantan Timur. Tidak terkecuali masalah di industri perkayuan yang dengan kapasitas terpasang mesin industri pengolahan kayu lebih besar dari suplai bahan baku kayu hutan lestari membuat para pelaku IUPHHK semakin bergairah melakukan penebangan secara intensif diluar aturan main. Hal ini tentu akan berdampak pula terhadap menurunnya penerimaan di sektor kehutanan di masa mendatang.

Apabila sasaran usaha penanaman kembali (melalui reboisasi, HTI, perkebunan "kategori hutan tanaman", agroforestry, hutan kemasyarakatan dan lain-lain) yang ditargetkan secara nasional seluas 300.000 - 500.000 hektar pertahun dapat terpenuhi, sesungguhnya itupun belum seimbang dengan laju degradasi atau pertambahan kerusakan hutan pada waktu yang bersamaan, yang ditaksir hampir mendekati dua kali lipatnya yaitu sekitar 500.000 - 900.000 hektar per tahun. Artinya pemerintah baik melalui program sektoral dan beserta sektor swasta perlu lebih mewujudkan secara konkrit usaha penanaman kembali lahan-lahan kritis, lahan tidur dan lain-lain supaya menjadi lebih produktif, baik melaui HTI, perkebunan, perhutanan sosial maupun hutan kemasyarakatan dengan memperkenalkan Pola Hutan Inti Rakyat (PHIR).

Kekhawatiran kita adalah, jika hutan mengalami kerusakan, maka ekosistem yang amat penting ini tidak lagi dapat menjalankan fungsinya dalam peranan ekologis ("ekonomi jangka panjang") serta peranan sosial ekonominya ("ekonomi jangka pendek dan menegah"). Kondisi semacam ini pada akhirnya justru membawa kerugian yang besar bagi kita semua.

Dalam upaya menangani permasalahan dibidang kehutanan pemerintah pusat melalui Menteri Kehutanan menetapkan kebijakan dalam bentuk keputusan. Dalam hal ini, SK Menhut No. 456/Menhut-VII/2004, menetapkan 5 (lima) kebijakan prioritas bidang kehutanan periode 2005-2009 yaitu:

- Pemberantasan pencurian kayu di hutan negara (illegal logging) dan perdagangan kayu illegal (illegal timber trade);

- Revitalisasi sektor kehutanan khususnya industri kehutanan;

- Rehabilitasi dan konservasi sumberdaya hutan;

- Pemberdayaan ekonomi masyarakat di dalam dan sekitar kawasan hutan, dan

- Pemantapan kawasan hutan.

\section{Revitalisasi Kehutanan Kaltim Era Otonomi Daerah}

Pada era pelaksanaan Otonomi Daerah 5 tahun II, revitalisasi kehutanan lebih diarahkan pada (i) pembangunan Hutan Tanaman Industri (HTI), (ii) restrukturisasi industri kehutanan secara lebih efisien dan mempunyai keunggulan kompetitif, (iii) pengembangan pemanfaatan hasil hutan nir kayu, (iv) pengusahaan wisata alam, (v) pemanfaatan jasa lingkungan. Pengusahaan hutan alam mulai dikurangi (kuota) sejalan dengan kebijakan pemerintah pusat maupun daerah. 


\section{Perusahaan IUPHHK}

Jumlah perusahaan pemegang konsesi HPH (IUPHHK) terjadi peningkatan. Pada tahun 2000 jumlah perusahaan pemegang HPH sebanyak 82 perusahaan, meningkat menjadi 88 perusahaan $(9,76 \%)$ pada tahun 2004. Sejalan dengan peningkatan jumlah perusahaan IUPHHK, luas tebanganpun meningkat dari 62.735,80 hektar pada tahun 2000 menjadi $72.490,21$ hektar $(15,55 \%)$ pada tahun 2004. Luas tebangan yang paling ektrim terjadi pada masa transisi atau awal pelaksanaan Otonomi Daerah tahun 2001 yaitu mencapai 591.312,80 hektar atau meningkat 842,54\% dari tahun sebelumnya.

Meski demikian produksi kayu bundar ternyata tidak menunjukkan perbedaan yang cukup signifikan, bahkan cenderung terjadi penurunan. Jika pada tahun 2000 produksi kayu bundar sebanyak 4.707.447,40 $\mathrm{M}^{3}$. Pada tahun 2001 dengan luas tebangan yang meningkat sangat tajam, produksi kayu bundar yang tercatat hanya $4.509 .928,90 \mathrm{M}^{3}$ atau menurun sebesar 4,20\%. Hal ini mengindikasikan bahwa pada tahun 2001 penebangan tidak resmi (illegal logging) terjadi luar biasa pada era reformasi, transisi masa pemerintahan sentralisasi ke desentralisasi dan tahap awal pelaksanaan Otonomi Daerah di Propinsi Kalimantan Timur.

Sekitar 18,82 juta atau setara dengan produksi kayu bulat selama lima tahun periode 2000 - 2004 yang tidak jelas rimbanya. Setelah itu produksi kayu bundar Kaltim terus mengalami penurunan sampai dengan tahun 2003 yang hanya $1.162 .777,54 \mathrm{M}^{3}$.

Rataan produksi kayu bundar per hektar areal tebangan tahun 2004 sebesar 31,83 $\mathrm{M}^{3}$ menurun lebih dari separohnya produktivitas kayu bundar pada tahun 2000 yakni sebesar 75,04 $\mathrm{M}^{3}$ per hektar etat tebangan sebelum era Otonomi Daerah. Meskipun demikian produksi kayu bundar Kalimantan Timur masih memberikan kontribusi yang cukup besar $(24,10 \%)$ terhadap produksi kayu bundar nasional pada kurun waktu lima tahun (2000-2004) yaitu sebesar $64.553 .132 \mathrm{~m}^{3}$. Tabel 1 berikut memperlihatkan jumlah perusahaan, luas tebangan dan produksi kayu bundar Kalimantan Timur periode 20002004.

Tabel 1

Luas Areal Tebangan dan Produksi Kayu Bulat

\begin{tabular}{|r|r|r|r|r|}
\hline Tahun & $\begin{array}{r}\text { Jumlah } \\
\text { Perush. }\end{array}$ & $\begin{array}{c}\text { Luas } \\
\text { Tebangan } \\
\text { (ha) }\end{array}$ & $\begin{array}{c}\text { Produksi KB } \\
\mathbf{( m}^{\mathbf{3}} \mathbf{)}\end{array}$ & $\begin{array}{c}\text { Rata-rata } \\
\text { /ha }\end{array}$ \\
\hline 2000 & 82 & $62.735,8$ & 4.707 .447 & 75,036 \\
\hline 2001 & 82 & $591.312,4$ & 4.509 .929 & 7,627 \\
\hline 2002 & 82 & $91.094,38$ & 2.601 .806 & 28,562 \\
\hline 2003 & 71 & $93.921,38$ & 1.162 .778 & 12,380 \\
\hline & 88 & $72.490,2$ & 2.577 .180 & 35,552 \\
\hline & & $911.554,2$ & 15.559 .139 & --- \\
\hline
\end{tabular}

Sumber: Statistik Kehutanan (berbagai tahun penerbitan); Bappeda Prop. Kaltim, 2005 


\section{Pelaksanaan TPI, TPTI, dan TJTI}

Setelah puluhan tahun pengalaman pengelolaan hutan dengan persetujuan kehutanan (forestry agreement) dengan sistem sekarang ini, dinilai masih belum berhasil dalam tujuan pengelolaan hutan seperti konsep Tebang Pilih Indonesia (TPI), Tebang Pilih Tanam Indonesia (TPTI), atau Tebang Jalur Tanam Indonesia (TJTI) dan lain sebagainya. Kecenderungan yang terjadi adalah bahwa kawasan hutan semakin mengalami penciutan/penyusutan (depletion) dan bahkan terjadi degradasi yang cukup serius akibat eksploitasi, deforestrasi sumberdaya hutan secara besar-besaran. Kondisi ini terjadi karena dalam praktek pengusahaan hutan cenderung menebang tanpa melaksanakan pedoman sistem Tebang Pilih Indonesia (TPI) dengan lengkap dan benar sesuai dengan ketentuan yang berlaku. Kecenderungannya adalah:

- Pemegang IUPHHK-HA cenderung menebang kayu yang bernilai komersial dan kualitas tinggi, berdiameter besar (hight grading) untuk ekspor, sehingga mengurangi efisiensi pemanfaatan sumber yang optimal persatuan luas dalam rangka mengejar keuntungan yang sebesar-besarnya, atau untuk menutup biaya modal dan depresiasi alat-alat berat yang mahal harganya sehingga berusaha memperoleh profit yang maksimum (maximize profit) persatuan waktu.

- Melakukan tebang ulang atau cuci mangkok bila harga kayu bulat baik, dengan alatalat berat bekas operasi yang depresiasinya telah nol, sehingga biaya produksi menjadi rendah.

- Secara umum kurang memperhatikan kelestarian hutan karena diperbolehkannya sistem tebang kontrak dengan leveransir, IPK yang kemudian ditinggalkan karena targetnya hanya penebangan semata tanpa meperhatikan kerusakan hutan dan upaya penanaman kembali.

Data laporan pelaksanaan TPI, TPTI, dan TJTI pada areal IUPHHK hutan alam tidak tersaji dengan baik dari pihak perusahaan maupun kontraktor lapangan. Sehingga cukup mempersulit dalam melakukan pengawasan. Meski demikian sesungguhnya telah dapat disimpulkan bahwa setelah lebih dari 35 tahun praktik pelaksanaan TPI, TPTI maupun TJTI ternyata gagal. Hal ini terbukti tidak ada satupun perusahaan yang pada pasca konsesi I HPH dapat kembali pada blok tebangan awal. Potensi kayu pada putaran kedua sudah sangat rendah sehingga hanya dapat dilakukan cuci mangkok atau IPK untuk budidaya dan semacamnya. Untuk mengetahui kondisi lapangan yang sebenarnya dapat dilakukan dengan berbagai upaya pengawasan, monitoring atau penelitian dan evaluasi dengan komitmen yang kuat terhadap upaya pelestarian hutan alam yang merupakan titipan generasi penerus bangsa.

Sebagai catatan penting bahwa kegiatan TPTI, penanaman kanan kiri jalan eksploitasi maupun penanaman areal non produktif dilaksanakan dengan persentase luas yang sangat rendah dari realisasi penebangannya. Luas penebangan pada areal hutan IUPHHK selama 5 tahun terakhir (2000-2004) tercatat 911.554,2 hektar, sedangkan realisasi pengayaan dan rehabilitasi TPTI hanya 38.781,52 hektar (4,25\%). Penanaman areal non produktif seluas 9.707,04 hektar $(1,06 \%)$ dan Penanaman kanan-kiri jalan seluas $7.454,61$ hektar $(0,82 \%)$.

\section{Ijin Pemanfaatan Kayu (IPK)}

Sesuai petunjuk teknis ijin pemanfaatan kayu diberikan pada areal yang akan dilakukan land clearing untuk kegiatan hutan tanaman, perkebunan, pemukiman, pertambangan dan lain sebagainya. Selama lima tahun terakhir luas areal yang telah diberikan ijin pemanfaatan kayu (IPK) untuk kepentingan perkebunan selama lima belas 
tahun terakhir $(1990$ - 2005) seluas 1.252.560 Hektar, sementara realisasi peruntukannya hanya 171.580,50 hektar $(21,10 \%)$ disajikan pada tabel 2 .

Dengan kata lain, laju peningkatan pemanfaatan kayu yang dikeluarkan melalui IPK delapan kali lebih cepat dari pada realisasi pruntukannya. Sementara realisasi untuk HTI baru mencapai $14,42 \%$ dari $1.183 .339,16$ hektar dalam kurun waktu yang sama. Lemahnya sistem pengawasan dan tidak tegasnya penerapan aturan yang berlaku menyebabkan laju degradasi hutan terjadi dengan lebih cepat.

Tabel 2:

Luas Pencadangan Areal, IPK dan Realisasi PeruntukanTahun 2000 - 2004

\begin{tabular}{|c|l|r|r|r|c|}
\hline No & Peruntukan & $\begin{array}{c}\text { Luas } \\
\text { Pencadangan } \\
\text { Areal (ha) }\end{array}$ & $\begin{array}{c}\text { Realisasi } \\
\text { IPK (ha) }\end{array}$ & $\begin{array}{c}\text { Realisasi Tanam } \\
\text { Peruntukan (ha) }\end{array}$ & $\%$ \\
\hline 1 & HTI & $1.215 .682,00$ & $1.183 .339,16$ & $26.434,33$ & 14,42 \\
2 & Perkebunan & $1.691 .726,30$ & $1.252 .560,00$ & $171.580,50$ & 21,10 \\
3 & Pertambangan & $246.571,10$ & $20.530,51$ & $8.998,16$ & 43,83 \\
4 & Transmigrasi & $180.319,00$ & n.a & n.a & - \\
\hline
\end{tabular}

Sumber: Analisis data sekunder berbagai sumber.

\section{Pembinaan Masyarakat Desa Hutan (PMDH)}

PMDH di Kalimantan Timur selama kurun waktu 9 tahun terakhir (196/97 - 2004) telah menghabiskan dana untuk berbagai kegiatan sekitar Rp 24,209 Milyar. Meski jumlah tersebut cukup besar, namun sesungguhnya nilainya sangat kecil (hanya $0,011 \%$ ) dibandingkan dengan nilai intrinsic kayu hasil penebangan yang keluar dari hutan dalam kurun waktu lima tahun terakhir yang ditaksasi sebesar Rp 23 Triliyun. Dalam kenyataannya, masyarakat desa disekitar kawasan hutan masih tetap miskin karena tricle down effect yang merembes ke penduduk dari pengusahaan hutan sangat kecil, sementara program PMDH terlalu bersifat makro, sehingga seolah tidak meninggalkan bekas dan tidak mampu manjawab tujuannya.

\section{Tahapan Revitalisasi Kehutanan}

Sejalan dengan rencana strategis Departemen Kehutanan, sasaran revitalisasi kehutanan mencakup berbagai kegiatan dengan indikator keberhasilan sebagai berikut.

1. Pengembangan komunikasi efektif untuk mewujudkan komitment bersama para pihak penyelenggaraan pembangunan kehutanan yang lebih terarah dan sistematis, termasuk juga dalam meretivitalisasi sektor kehutanan ke depan. Indikator keberhasilan adalah adanya dukungan dan komitmen kuat para pihak sektor kehutanan serta peningkatan kesadaran dan dukungan dari sektor terkait lainnya.

2. Pengembangan prakondisi pembangunan kehutanan, dengan indikator keberhasilan tersedianya rencana, data dan informasi sumber daya hutan dan kehutanan yang realiabel dan akurat sesuai tingkatan unit pengelolaan, potensi penutupan lahan, kayu komersil dan non komersil, potensi non kayu, hidupan liar, jasa lingkungan dan wisata. 
3. Pemantapan kawasan hutan untuk menjamin kepastian pengelolaan hutan dan pengusahaan hasil hutan.

4. Melakukan fasilitas dalam pengelolaan hutan lestari pada IUPHHK hutan alam dan IUPHHK hutan tanaman, serta pengelolaan hutan berbasis masyarakat. Indikator keberhasilan berjalannya pengelolaan hutan lestari di unit pengelolaan hutan (IUPHHK hutan alam dan IUPHHK hutan tanaman, serta pengelolaan hutan berbasis masyarakat). Dalam periode 5 tahun ke depan (2006-2010). Pengelolaan hutan lestari dapat berjalan memiliki setifikat Pengelolaan Hutan Lestari (PHL).

5. Melakukan revitalisasi dan merestrukturrisasi industri kehutanan yang lebih obyektif dan terbuka terhadap pasar domestik dan global. Industri-industri skala kecil milik masyarakat dilakukan pembinaan untuk menjamin mutu dan kontinyuitasnya. Indikator keberhasilan performance industri kehutanan efisien dan mampu bersaing secara global. Pada periode (2006-2010) diselenggarakan indikator keberhasilannya:

- Fasilitas peningkatan performance industri kehutanan 50\% dari industri yang ada, dengan indikator pencapaian industri kehutanan dengan kapasitas $6.000 \mathrm{~m} 3 /$ tahun dapat berjalan efisien dan kompetitif secara global.

- Peningkatan iklim usaha kecil dan menengah serta akses masyarakat kepada hutan.

- Memberikan jaminan akan ketersediaan bahan baku untuk UKM kehutanan.

6. Pembangunan dan pengembangan hutan tanaman dan hutan rakyat untuk mendukung penyediaan bahan baku untuk memenuhi kebutuhan konsumsi masyarakat domestik dan global. Indikator keberhasilannya hutan tanaman terbangun dan berproduksi secara lestari serta mampu mendukung kebutuhan industri kehutanan. Pada periode (2006-2010) indikator keberhasilannya adalah fasilitasi pembangunan hutan tanaman industri yang didukung oleh industri yang efisien, dengan indikator pencapaian $70 \%$ dari hutan tanaman yang direncanakan beroperasi dengan produksi mencapai $150 \mathrm{~m} 3 / \mathrm{ha}$, serta penyerapan tenaga kerja yang terlibat meningkat dari penyerapan tenaga kerja pada tahun 2005.

7. Mengupayakan peningkatan produk bukan kayu (non timber forest product), dengan indikator pendapatan produk hasil hutan non kayu meningkat dan beragam. Dalam kurun waktu 2006-2010 diharapkan pencapaian pendapatan produk hasil hutan non kayu meningkat dari tahun sebelumnya.

8. Mengoptimalkan Penerimaan Negara Bukan Pajak (PNBP) dan Dana Reboisasi (DR). Pada tahun 2006-2010 indikator pencapaian jumlah PNBP terus meningkat setiap tahunnya. Dengan adanya sasaran dan indikator pencapaian tersebut, diharapkan akan terjadi dampak langsung maupun tidak langsung (outcome) berupa: (1) nilai tambah industri kehutanan meningkat, (2) peningkatan penyerapan tenaga kerja, (3) peningkatan devisa, (4) peningkatan ekonomi wilayah, (5) peningkatan kesejahteraan masyarakat, 6) pengelolaan lebih efisien dan kompetitif, (7) tercapai pengelolaan hutan yang berkelanjutan, disamping menyelenggarakan perbaikan kualitas.

\section{Pembangunan Kehutanan Era Otonomi Daerah ke- (2006-2010)}

Pembangunan kehutanan Provinsi Kalimantan Timur era Otonomi Daerah 5 tahun II, merupakan kelanjutan implementasi lima kebijakan Departemen Kehutanan yang telah ditetapkan melalui Surat Keputusan Menteri Kehutanan No. 7501/Kpts-II/2002 tanggal 7 Agustus 2002. Program kegiatan pembangunan tersebut meliputi: 
1. Pemberantasan aktivitas pencurian kayu (illegal logging) dan perdagangan kayu secara liar (illegal trade):

- Mendukung dan memperkuat kerjasama Mabes TNI-POLRI dalam pelaksanaan operasi wanalaga, wanabahari, operasi khusus wilayah perbatasan Kalimantan Timur dengan Serawak Malaysia dan operasi fungsional.

- Memperkuat kerja dengan Mabes POLRI-Kejaksaan dan Kehakiman untuk mempercepat proses persidangan pencurian kayu.

- Melanjutkan kampanye Nasional anti pencurian kayu terutama bagi aparat kehutanan Propinsi Kalimantan Timur.

- Menertibkan tata usaha kayu hasil hutan untuk mencegah penyelundupan dan atau perdagangan kayu illegal.

- Memperkuat koordinasi antara pusat dengan daerah dalam pemberantasan illegal logging.

2. Penanggulangan Kebakaran Hutan

- Pembentukan Brigade Pengendalian Kebakaran Hutan

- Operasionalisasi pengendalian kebakaran hutan di daerah-daerah paling rawan.

- Pengembangan sistem peringatan dini bahaya kebakaran hutan.

- Kampanye pengendalian kebakaran hutan.

- Penyiagaan Posko Radio Komunikasi dan Stasiun Pengendalian Kebakaran.

3. Restukturisasi Sektor Kehutanan

- Penerapan soft landing (penurunan jatah tebangan).

- Penilaian kinerja pengelolaan hutan alam produksi oleh LPI

- Penilaian terhadap IUPHHK/HPH. Pembentukan Pokja Restrukturisasi HTI untuk mempersiapkan restrukturisasi pengelolaan hutan tanaman.

- Penilaian kinerja usaha pemanfaatan hutan tanaman oleh LPI.

- Rekstrukturisasi Indusrti primer hasil hutan kayu (IUPHHK). Akan dievaluasi/verifikasi terhadap Industri yang terdaftar pada BRIK.

- Terus mendorong upaya pembangunan hutan tanaman yang baru.

4. Rehabilitasi dan Konservasi Sumber Daya Alam (SDA)

- Melakukan Gerakan Nasional Rehabilitasi Hutan dan Lahan (GN-RHL).

- Penyusunan Master Plan RHL di provinsi.

- Melanjutkan pengembangan social forestry.

- Melanjutkan pengembangan usaha perhutanan rakyat di wilayah DAS.

- Mendukung pengembangan sistem pengelolaan kawasan konservasi melalui pola collaborative management antara lain Taman Nasional Kayan Mentarang (TNKM) dengan Dewan Penentu Kebijakan Pengelolaan Taman Nasional Tingkat Kabupaten.

\section{Kebijakan Prioritas dan Reorientasi Kebijakan Sektor Kehutanan}

Periode lima tahun mendatang (2006-2010) sumber daya hutan berupa kayu yang berasal dari hutan alam untuk sementara tidak lagi menjadi andalan perekonomian daerah maupun nasional, paling tidak untuk jangka waktu sepuluh sampai dua puluh tahun kedepan. Produksi kayu dari hutan alam yang selama ini merupakan hasil hutan yang utama akan dikurangi (kuota) secara bertahap, sementara itu, untuk mengimbangi penurunan kegiatan akibat penurunan produksi kayu, Pemerintah akan mendorong pemanfaatan non timber forest product (NTFP) dan jasa lingkungan. Seiring dengan itu produksi kayu dari hutan tanaman (HTI) terus ditingkatkan. Penetapan kebijakan prioritas Dinas Kehutanan Propinsi 
Kalimantan Timur pada dasarnya adalah mendukung dan melanjutklan kebijakan Departemen Kehutanan 2005-2009 yang merupakan kelanjutan dan modifikasi dari 5 kebijakan prioritas pada tahun 2004 belum tuntas dilaksanakan dan akan terus diperbaiki dalam tataran implementasi di lapangan.

Adapun kebijakan prioritas bidang kehutanan yang perlu mendapat perhatian serius ini meliputi hal-hal sebagai berikut:

1. Penanggulangan pencurian kayu di hutan negara dan perdagangan kayu illegal. Kebijakan ini dimaksudkan untuk:

- Menegakkan moral, tatanan sosial dalam bernegara dan berbangsa.

- Tegaknya kepastian hukum di bidang kehutanan.

- Mendorong iklim usaha dibidang kehutanan secara sah dan benar.

- Meningkatkan partisipasi berbagai pihak serta masyarakat dalam melestarikan hutan.

- Menjamin keberadaan hutan sebagai modal pembangunan.

2. Revitalisasi Kehutanan (industri kehutanan). Kebijakan revitalisasi dipandang penting untuk:

- Menciptakan industri kehutanan yang tangguh dan mampu bersaing secara global, terwujudnya struktur industri pengolahan kayu yang efisien, berwawasan lingkungan dengan produk yang dihasilkan mempunyai daya saing tinggi.

- Meningkatkan penyerapan tenaga kerja

- Meningkatkan pendapatan bagi masyarakat dan negara

- Mewujudkan pengelolaan hutan secara lestari (Sustainable Forest Management) yang mendukung pengembangan industri kehutanan.

3. Rehabilitasi dan Konservasi Sumberdaya Hutan. Kebijakan ini menjadi prioritas mengingat kondishi hutan selama kurun waktu 40 tahun terakhir terus mengalami degradasi dan deplisi. Hal penting dalam kebijakan ini dimaksudkan untuk:

- Menjaga dan memelihara kebutuhan ekosistem hutan dan fungsinya

- Mempercepat pemulihan hutan yang kritis

- Meningkatkan daya dukung lingkungan (local, nasional maupun global)

- Meningkatkan manfaat hutan bagi kesejahteraan masyarakat

- Meningkatkan partisipasi masyarakat dalam memelihara hutan dan berusaha di sektor kehutanan

- Meningkatkan dan menjaga daya dukung Daerah Aliran Sungai.

4. Pemberdayaan Ekonomi Masyarakat di dalam dan sekitar Kawasan Hutan. Kebijakan ini penting untuk:

- Meningkatkan peran serta masyarakat dalam pembangunan kehutanan.

- Meningkatkan akses masyarakat setempat dalam pemanfaatan hutan

- Meningkatkan lapangan pekerjaan bagi masyarakat stempat

- Meningkatkan partisipasi dalam memelihara kelestarian hutan

- Meningkatkan kesejahteraan masyarakat sekitar hutan.

5. Pemantapan Kawasan Hutan. Kebijakan dasar ini perlu dalam upaya pengelolaan hutan lestari untuk mencapai hal-hal berikut:

- Menjamin/mempertahankan keberadaan kawasan hutan dan pemulihan hutan

- Menjamin berjalannya unit-unit pengelolaan hutan untuk berbagai pemanfaatan hutan dan hasil hutan

- Menjamin intensifikasi pengelolaan hutan dan hasil hutan

- Menjamin kelestarian usaha dan daya dukung kehidupan dari sumberdaya hutan. 
Setelah lebih dari 35 tahun pelaksanaan pengusahaan hutan dan sesudah lebih dari 25 tahun diterbitkan Pedoman Tebang Pilih Indonesia ternyata penerapanya jauh dari yang diharapkan. Menghadapi kenyataan sulitnya dilaksanakan pedoman tersebut perlu dicari jalan keluarnya, perlu kompromi antara pemerintah (sebagai pemilik hutan) dan pengusahaan hutan/pemegang IUPHHK (sebagai investor). Sedikitnya dapat diusulkan 3 alternatif yaitu:

1. Untuk mengakomodasi tebang ulang (cuci mangkok) dan kebutuhan bahan baku kayu yang mendesak bagi industri, maka sitem tebang pilih Indonesia diubah menjadi siklus tebangan monocyclic (yang sekarang berlaku adalah duocyclic sehingga dibuat tebangan sekaligus artinya semua kayu yang dapat dimanfaatkan secara ekonomis dipungut semaksimal mungkin per hektarnya.

2. Alternatif kebalikannya ialah membiarkan tebang ulang (cuci mangkok) dipraktekkan asal dilaksanakan menurut aturan atau perencanaan tertentu. Seperti diketahui, antara siklus tebangan dan persentasi volume kayu yang boleh ditebang ada korelasinya. Kalau siklus tebangan sama dengan rotasi maka $100 \%$ volume kayu boleh ditebang, sebaliknya kalau siklus tebangan 35 tahun,10 tahun, atau 5 tahun (policyclic) maka yang boleh dipanen mestinya semakin kecil.

3. Diadakan kerja sama kelembagaan dalam melaksanakan permudaan. Lebih dikhususkan bagi IPK, Alternatif ini memerlukan ekstra pengawasan pada blok tebangan, yaitu tidak boleh menebang diluar blok. Tetapi pekerjaan penebangan menjadi lebih sederhana karena pekerjaan seperti menunjukkan pohon yang ditebang dengan penandaanya, inventarisasi kembali pohon setelah tebangan dan lain-lain tidak perlu dilakukan. Tidak perlu ada pilihan sistem silvikultur dan penentuan pohon inti karena akan dipermuda total (close planting).

Besarnya volume kayu yang dipungut bergantung pula pada riap yang dinyatakan dalam persentase stok yang sedang tumbuh (terhadap growing stock). Kalau riap (dalam prosentase) cukup tinggi, volume kayu yang boleh dipungut per siklus tebangan makin tinggi. Masalah yang timbul adalah berapa pertumbuhan bersih yang sebenarnya, sebagaimana permudaan pohon pada setiap siklus, dan bagaimana kerusakan penebangan terhadap tegakan tinggal setiap siklus. Untuk itu perlu dicari teknik manajemen dan silvikultur yang sesuai untuk sistem ini. Dalam menetapkan sistem pungutan Iuran Ijin Usaha Pungutan Hasil Hutan Kayu (IHPHTI-IHPH), Provisi Sumber Daya Hutan (PSDH) terutama untuk dapat menjamin kelestarian sumberdaya hutan, perlu ditekankan hal-hal sebagai berikut:

1. IIUPHHK dipungut seoptimal mungkin yang dapat memberikan jaminan upaya rehabilitasi lahan hutan yang besar kemungkinan akan terjadi degradasi dan gangguann fungsi lingkungan akibat usaha pemungutan hasil hutan kayu.

2. PSDH harus sedapat mungkin mencerminkan nilai atau biaya tegakan (stumpage costs) yaitu dengan sistem nilai yang diturunkan dari harga kayu bulat atau kayu olahan ekspor (derived value) dan disesuaikan setiap tahunnya.

3. Alokasi penerimaan PSDH harus benar-benar memadai dan ditunjukkan untuk perbaikan nilai tegakan dihutan yang bersangkutan.

4. Pungutan hasil hutan harus dapat mencerminkan biaya kompensasi lingkungan dan biaya kompensasi kelangkaan yang selama ini dianggap biaya sosial (social costs) dan dibebankan tanggung jawabnya kepada pemerintah sebagai pelayanan umum (public services).

5. Pungutan tegakan bersama-sama dengan pungutan hutan lainnya, harus dapat membiayai pengawasan yang lebih intensif terhadap pelaksanaan manajemen hutan, dan dapat mengurangi kelemahan pelaksanaan sistem Tebang Pilih Indonesia yang lalu. Kenyataan 
hingga saat ini hutan alam masih merupakan luasan hutan produksi yang cukup besar. Pembangunan Hutan Tanaman Industri (HTI) dibebankan pada Dana Reboisasi (DR) sedangkan untuk hutan produksi alam melalui program TPI, TPTI dan TJTI tidak berjalan sesuai dengan konsep yang sesungguhnya.

6. Pengusahaan hutan menganggap pengeluaran permudaan dan pemeliharaan hutan untuk panenan di kemudian hari adalah hasil yang tidak pasti (uncertainty). Oleh karena itu pengeluaran untuk itu dihambat atau pertimbangan jangka waktu kontrak pengusahaan hutan hanya 20 tahun, adalah suatu jangka waktu yang dipandang tidak cukup untuk suatu investasi yang menguntungkan (profitable investment). Investasi yang hasilnya baru dapat diperoleh setelah waktu yang lama sangat peka terhadap suku bunga modal. Pengusaha hasil hutan kayu tidak tertarik pada pedoman tebang pilih Indonesia karena persepsi ini. Perlu adanya rumusan baru yang dikemas lebih menarik.

7. Dalam prosedur perijinan (RKT), mestinya dikaitkan dan menjadi tolok ukur untuk rencana kegiatan tahun berikutnya. Artinya jika perusahaan tidak/belum melaksanakan kegiatan TPTI dengan benar tidak perlu direkomendasi untuk kegiatan penebangan berikutnya. Hal ini dipandang perlu adanya pengawasan yang ketat dan bersungguhsungguh oleh petugas kehutanan maupun pihak-pihak terkait lainnya.

\section{Agenda Kedepan: Sebuah Catatan Penutup}

Dalam upaya mendorong percepatan pembangunan Hutan Tanaman, pemerintah pusat telah mengeluarkan berbagai kebijakan berupa paket Deregulasi. Paket ini bertujuan untuk mendorong dan menciptakan iklim berusaha yang kondusif dan menggairahkan para investor swasta/BUMN di bidang pembangunan hutan tanaman. Paket deregulasi dimaksud terdiri dari 3 aspek:

1. Aspek Restrukturisasi Kebijakan. Harus diakui bahwa pembangunan HTI membutuhkan dana yang besar, sehingga persoalan dana seringkali menjadi masalah. Dalam mengatasi permasalahan dana dalam pembangunan HTI oleh perusahaan HTI (patungan/BUMN), Menteri Kehutanan telah menerbitkan SK. No. 43/Menhut-II/2004 yang mencabut SK Menhut No.8678/Kpts-II/2002 dan memberlakukan kembali seluruh ketentuan yang diatur di dalam SK. Menhut No,4895/Kpts-II2002 tentang kriteria dan indikator penilaian usaha pengusahaan HTI patungan dan HTI BUMN beserta lampirannya, dan SK. Menhut No. 46/Menhut-II/2004 ditetapkan untuk mengatur komposisi pendanaan perusahaan HTI patungan sebagai akibat adanya dana talangan dari perusahaan swasta.

2. Aspek Akselerasi. Dalam rangka penanganan kawasan hutan yang rusak untuk pembangunan hutan tanaman dan pembangunan HTI yang dibangun dengan dana talangan swasta, pemerintah pusat telah mengeluarkan beberapa kebijakan yang menunjang upaya percepatan pembangunan hutan tanaman, antara lain:

- Penyederhanaan penyusunan, penilaian dan pengesahan RKT UPHHK-HT melalui keputusan Menhut No. 45/Kpts-II/2004 tentang perubahan Keputusan Menhut No. $151 / \mathrm{Kpts}-\mathrm{II} / 2003$.

- Surat Keputusan Menteri Kehutanan Nomor 44/Menhut-II/2004 telah merubah SK Menhut Nomor 33/Kpts-II/2003 tentang Tata Cara Penyelesaian Hak Pengusahaan Hutan Alam atau Hak Pengusahaan Hutan Tanaman yang telah mendapatkan Persetujuan Prinsip Berdasarkan Permohonan.

- Surat Keputusan Menteri Kehutanan Nomor 162/Kpts-II/2003 jo SK Menhut Nomor 101/Menhut-II/2004 tentang Percepatan Pembangunan Hutan Tanaman untuk Pemenuhan Bahan Baku Industri Pulp dan Kertas. 
3. Aspek Peningkatan Daya Tarik Investasi. Pembangunan Hutan Tanaman mempunyai resiko tinggi, sulit diprediksi dan pada umumnya pengusaha hutan tanaman menganggap pengeluaran permudaan buatan dan pemeliharaan sampai panenan di kemudian hari adalah hasil yang tidak pasti (uncertainty). Pemerintah telah mengeluarkan kebijakankebijakan sebagai berikut.

- Peluang akuisisi dan merger terhadap HTI yang akumulasi modal dan kemampuan finansialnya lemah dengan investor baru dan melanjutkan HTI yang telah eksis.

- Keputusan Menhut No. 47/Menhut-II/2004 yang memuat Kebijakan, Tata Cara dan Persyaratan Pengambilan Saham pada HPH dan HTI yang berbentuk Perseroan Terbatas (PT).

- Keputusan Menteri Kehutanan Nomor 308/Kpts-II/2003 tentang denda atas keterlambatan pengembalian pinjaman dan penjadualan kembali pembayaran pengembalian pinjaman Dana Reboisasi oleh perusahaan HTI Patungan dan BUMN.

Selain hal-hal diatas, maka untuk menghasilkan efek yang nyata terhadap kesejahteraan sosial ekonomi masyarakat, maka kebijakan pengelolaan kehutanan perlu benar-benar memperhatikan prinsip pengelolaan hutan bersama rakyat. Dalam hal ini, pembagian hasil yang dapat dinikmati oleh rakyat antara lain berupa jasa kerja, jasa manajemen dan jasa produksi hasil panen kayu. Pada saat yang bersamaan, pola kemitraan dalam rangka membangun hutan rakyat harus dikembangkan, melalui bentuk-bentuk berikut ini:

- Hutan Inti Rakyat (HIR) dan atau pengelolan hutan tanaman Sistem Bagi Hasil dengan ratio 60:40 artinya suatu pengelolan hutan yang dilakukan oleh rakyat dengan modal seluruhnya dari perusahaan dengan pembagian hasil $60 \%$ untuk perusahaan pemodal dan $40 \%$ bagi rakyat pengelola.

- Koperasi Perhutanan Tanaman: sumber modal dari swasta, sedangkan koperasi melaksanakan kegiatan pengelolaan. Pembagian hasil 20:80, yaitu 20\% untuk koperasi dan $80 \%$ untuk perusahaan pemberi modal.

Alternatif kebijakan lainnya dalam pengelolaan hutan adalah Pola Tiga Dimensi, yaitu pola pembangunan hutan rakyat yang dikombinasikan dengan tanaman keras produksi multipurpose species (buah, lateks, kulit) tanaman perkebunan "penghasil kayu pada akhir daur" dengan tanaman hutan dan ternak mamalia, dimana pemukiman dibangun didalam kebun hutan. Sumber dana dapat berasal dari perusahaan sebagai bentuk pembinaan masyarakat sekitar hutan tanaman dan atau sumber dana dari pemerintah berupa proyek/program pengentasan kemiskinan dan pemberdayaan masyarakat desa di sekitar hutan, baik APBN/APBD.

Akhirnya, revitalisasi industri kehutanan Kalimantan Timur perlu dilakukan melalui Badan Revitalisasi Industri Kehutanan (BRIK), sehingga nilai hutan pada aspek industrialisasi yaitu proses industri melalui nilai tambah dan lapangan kerja menjadi lebih baik. Restrukturisasi industri ini dimaksudkan untuk upaya-upaya pembinaan dan fasilitasi lebih lanjut oleh Pemerintah. Sebagai Eksportir Terdaftar Produk Industri Kehutanan (EPTIK), industri yang dinilai perlu dilakukan upaya perbaikan melalui misalnya down sizing, reengineering atau marger beberapa industri. Dalam rangka kesinambungan dan diversifikasi sumber bahan baku IPHHK, dari produksi hutan rakyat perlu mengembangkan kegiatan community development dengan membantu bahan tanaman untuk masyarakat dalam menjalin hubungan kerja sama pengembangan hutan rakyat. 


\section{Daftar Referensi}

Badan Perencanaan Daerah Kalimantan Timur, 2005. Buku Saku, 2005. samarinda.

Daroni, 2006. Evaluasi 35 Tahun Pengelolaan Hutan Alam di Kalimantan Timur. Makalah Workshop Regional Kalimantan, Pengelolaan Sumberdaya Alam Dan Lingkungan Hidup Untuk Pembangunan Berkelanjutan.

Daroni, 1999. Pembangunan Ekonomi Kerakyatan Berbasis Kehutanan, Perkebunan dan Peternakan (Pola Tiga Dimensi sebagai salah satu Sistem Pengembangan Hutan Rakyat). Dinas Kehutanan Propinsi Kalimantan Timur. Samarinda.

Departemen Kuhutanan, 2003. Keputusan Menteri Kehutanan Nomor: 126/KPTS-II/2003, Tentang Penatausahaan Hasil Hutan.

Departemen Kehutanan, 2005. Keputusan Menteri Kehutanan Nomor SK. 474/MenhutVII/2004 tentang encana Kerja Kementrian Negara/Lembaga (Renja-KL). Departemen Kehutanan tahun 2005.

Departemen Kehutanan, 2005. Peraturan Menteri Kehutanan Nomor:P.04/Menhut-II/2005, tentang Rencana Stratyegis Kementrian Negara/Lembaga (Renstra-KL), Departemen Kehutanan Tahun 2005-2009. Jakarta.

Departemen Kehutanan, 2004. Surat Keputusan Menteri Kehutanan No.SK.456/MenhutVII/2004, tentang Penetapan 5 (lima) kebijakan prioritas bidang kehutanan periode 2005-2009,

Dinas Kehutanan Propinsi Kalimantan Timur, 2004. Kalimantan Timur Dalam Angka.

Dinas Kehutanan Provinsi Kalimantan Timur, 2005. Statistik Kehutanan Provinsi kalimantan Timur 2004. Samarinda.

Soemitro, A., 1978. Analisa Investasi Penanaman Hutan, Bagian Penerbitan Yayasan Pembina Fakultas Kehutanan, Universitas Gadjah Mada. Yogyakarta.

Suparmoko dan Usman, W., 1988. Ekonomi Sumberdaya Alam, Karunika Universitas Terbuka. Jakarta. 